\title{
From Zero-Sum to Positive Sum: Cultivating Political Settlement and Reform in Libya
}

\author{
SHATHA SBETA* and MOHAMED ABUFALGHA ${ }^{* *}$ \\ * De-Orientalizing Art Organization, U.S. \\ ORCID No: 0000-0003-3196-2045 \\ ** Arab Barometer, U.S. \\ ORCID No: 0000-0003-3435-765X
}

\begin{abstract}
In this commentary, we advocate for a comprehensive framework to address the political, economic, and social challenges facing Libya. The proposal draws a clear roadmap that begins with establishing trust and extending the authority of the government across the Libyan territory. As the waters get muddied with poorly conceived political proposals, the project advocated for in this commentary stands out as a genuine, empirically-based framework toward a solution for the Libyan crisis.
\end{abstract}

Keywords: Political Reform, Democratization, Libya 


\section{Contextual Overview}

T he United Nations Support Mission in Libya (UNSMIL) led an initiative to bring political rivals to the negotiation table in early 2015. By that time, Libya had sunk into chaos, amid political and economic crises. The problem had begun a year earlier at the end of the General National Congress (GNC) term. On February 14, 2014, a military officer named Khalifa Haftar announced the suspension of both the GNC and the government on television. Although his coup attempt failed, it marked the beginning of years of conflict over power and political legitimacy in the country.

In May 2014, Haftar launched a military campaign under the name Operation Dignity (Karama) to seize power over Eastern Libya, using the banner of counter-terrorism efforts. Haftar attempted to create an alliance with factions in Western Libya to expand his influence. As a response, anti-Haftar forces, which included some Islamist and revolutionary factions, launched Operation Libya Dawn (Fajr Libya) and waged a preemptive war against Haftar's allies in Tripoli. The launching of Libya Dawn prevented the House of Representatives (HoR), which had been elected in June 2014, from assuming its responsibilities. A later decision by the High Constitutional Court would invalidate the elections. As a result of Operation Libya Dawn, the HoR fled to Tobruk along with the interim government at the time. Operation Libya Dawn sought to fill the political vac- uum left. To this end, it called upon the GNC to re-assume power as the legitimate legislative body. The GNC did so, creating a parallel government and calling it the 'Salvation Government.' By then, a clear divide had surfaced, and Libya ended up with two governments, two legislative bodies and two camps of armed forces.

With the doubling of governing bodies, services and living conditions deteriorated. Economic issues ranging from lack of liquidity and inflation to lack of foreign currency prevailed, mostly due to the oil shutdown. Libyans were seen standing in long lines at the banks for hours and days, only to be told to come back the next day. Armed clashes and military confrontations became a regularity in several parts of the country, including Tripoli and Benghazi, Libya's two biggest cities. In short, a bloody civil war ensued.

After months of this new reality, voices began to rise demanding an end to the division and especially to the war. In early 2015, some members from the Libya Dawn and Dignity camps agreed to attend talks while others refused. The UNSMIL facilitated several meetings between the rivals, who rejected multiple proposals for peace. Morocco hosted the rivals again in December 2015 for another round of meetings. The two sides finally reached and signed a peace agreement on December 17, 2015 in the city of Skhirat, Morocco. The agreement is known formally as the Libyan Political Agreement (LPA) and colloquially as the Skhirat Agree- 
ment. Per the agreement, two main bodies were created. The first was the Presidential Council, and the other was the Government of National Accord (GNA). The agreement also established the High Council of State (HCS), which consisted of members of the former GNC, as an advisory body to the GNA and the HoR. The UN Security Council and several powers quickly endorsed the agreement and recognized the GNA as the sole legitimate government in Libya.

Internally, however, support for the LPA and the GNA was not secured as quickly. Several actors within the Libya Dawn and the Dignity camps rejected the agreement and sought to prevent the GNA from assuming power. Some Tripoli-based militias threatened to attack the Presidential Council if it moved to Tripoli. The Council delayed its move until the end of March 2016, two months after its initial meeting in Tunisia. The GNA was confined in a naval base for several months after it moved to Tripoli. Politically, the HoR initially supported and endorsed the GNA, but later rescinded its confidence and did not approve the GNA in the summer of 2016. Instead, it kept the Interim Government which was supposed to be dissolved. Thus, the objective of creating a unified government was unfortunately not achieved, and the HoR became the GNA's main rival. In addition, the GNA did not have a supporting military force, so it failed to control Tripoli. The 2016 war against ISIS in Sirte helped the GNA gain more international support. The loose alliance between the GNA and

\section{In early 2015, some members from the Libya Dawn and Dignity camps agreed to attend talks while others refused. The UNSMIL facilitated several meetings between the rivals, who rejected multiple proposals for peace}

the forces of the al-Bunyan al-Marsoos Operation also provided the government with a glimpse of hope at harnessing local support.

\section{Why the LPA Failed to Stabilize and Democratize Libya}

According to the final text, the LPA was based on four principles: "ensuring the democratic rights of the Libyan people, the need for a consensual government based on the principle of the separation of powers, oversight and balance between them, as well as the need to empower state institutions like the GNA so that they can address the serious challenges ahead, respect for the Libyan judiciary and its independence." ${ }^{1}$ To assess the outcomes of the LPA, we must evaluate the extent to which the emerging institutions upheld its principles.

Almost five years after signing the agreement, the "democratic rights of 


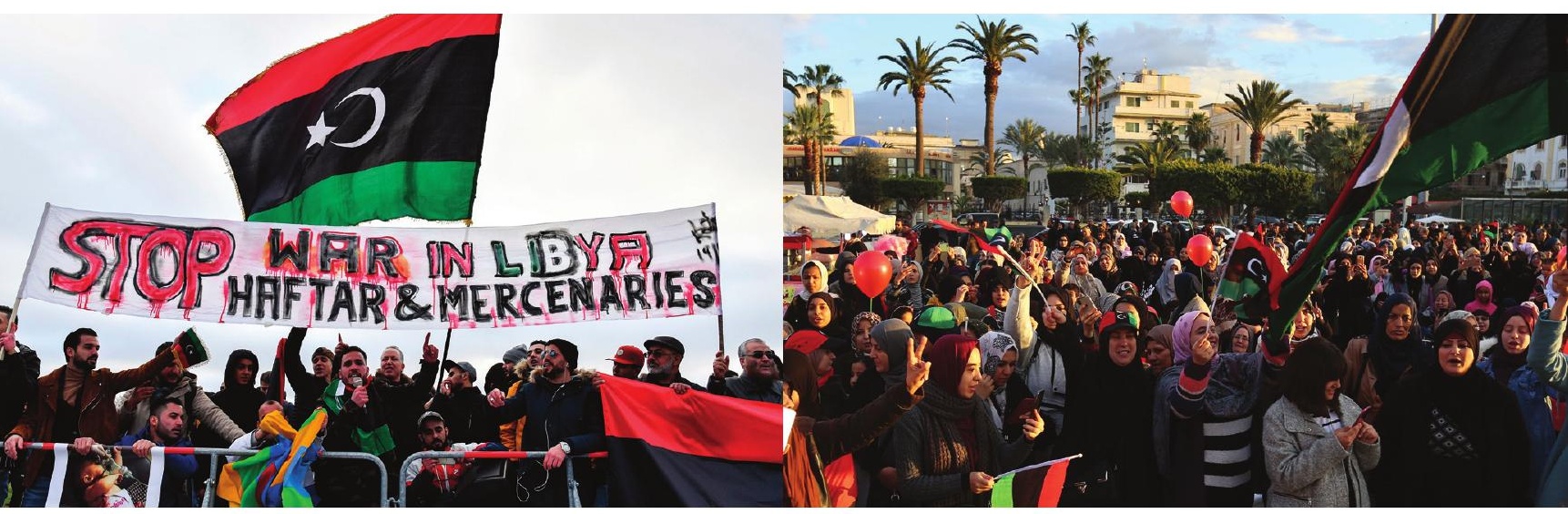

Demonstrators showing their support of the UN-recognised GNA and anger against Khalifa Haftar's illegal war to take control of Libya, in Martyrs' Square (R), Tripoli, January 10, 2020, and outside the Peace Summit on Libya (L), in Berlin, January 19

2020.

(L) JOHN MACDOUGALL / AFP via Getty Images

(R) HAZEM TURKIA /

the Libyan people" have been ignored and forgotten. The last time the public had a say in who governs them was in 2014. The GNA, the HoR, and the HCS failed, either intentionally or unintentionally, at creating an appropriate environment for holding general elections. Indeed, elements within each body are not willing to give up the power they have; thus, they fight every call for elections. Additionally, disagreements between the three bodies and the government's failure to stabilize the country made it impossible for any election to take place. On May 2, 2018, suicide attackers from ISIS stormed the headquarters of the High National Election Commission (HNEC), killing a dozen and injuring many more. ${ }^{2}$ Such incidents hinder and complicate the work of the commission, making it nearly impossible. More directly, the Libyan Arab Armed Forces (LAAF) militia, led by Khalifa Haftar and allied with the HoR, attacked polling stations in the southern town of Traghan. The attack put a halt to the municipal elections. ${ }^{3}$ Haftar himself suggested, on mul- tiple occasions, that the country is not ready for democracy. ${ }^{4}$ Following Serraj's insistence on holding Libyan General Elections in March 2021, the head of HNEC said that the commission was not ready to hold elections due to lack of funding and the GNA has "been putting pressure on HNEC for five years and that it had reached such an extent that it was unable to manage its normal affairs." 5

As for the separation of powers and "the need for a consensual government," the current status reflects a lack of both. As mentioned above, the HoR had refused to grant the GNA a vote of confidence because the HoR had no control over the government's base in Tripoli. Instead, the HoR reinstated the Interim Government in the East. Since the summer of 2016, the HoR has refused to approve the GNA. Thus, the country has continued to have two parallel governments despite the agreement to the contrary, and a consensual government has yet to be formed. Neither have the current bodies managed to 
achieve a separation of powers. In Western Libya, the GNA played the role of both, the executive and legislative branches of government for a long time, given that the HCS was merely an advisory body. This issue has caused the GNA to clash with the Audit Bureau and the Central Bank several times over the course of the last four years. Both the Bureau and the Bank found the GNA's overreach troubling. These clashes are to a certain extent responsible for the worsening of living conditions. In Eastern Libya, the Interim Government has continued to hold the executive powers on paper. However, the LAAF was the actual, powerful body that ran the show.

Another main principle in the agreement was empowering state institutions, including the GNA. Yet the HoR and even the HCS sought to undermine the government early in the process. Moreover, the claims as to GNA's incompetence and corruption added insult to injury. The various bodies that came out of the LPA failed at carrying out their responsibilities toward the public. A 2019 survey by the Arab Barometer showed that Libyans "have virtually no trust in political institutions in their country." ${ }^{\text {Only }} 10$ percent said they trust the government or the parliament. Corruption and incompetence at the leadership level contributes to this low level of trust. Less than 20 percent believe that political leaders care about the needs of the general public.

In short, if we evaluate and assess the outcomes of the LPA based on
Both the UN recognized GNA and the challenging HoR formed alliances with regional powers, which came at the expense of Libya's

\section{sovereignty}

its foundational principles, the inevitable conclusion is that the LPA has failed massively. The LPA's failure is a natural result of several factors that characterize the agreement itself. One of these factors is that the preparatory talks were held outside the country between representatives of governing bodies along with some politicians and political activists. To large segments of Libyans, the entire process seemed detached from their daily lives and struggles. Neither the UNSMIL nor the existing bodies took it upon themselves to conduct outreach campaigns to mobilize the public in support of the agreement. Thus, even though some Libyans were initially excited about the LPA, their excitement was short-lived; many others were skeptical and viewed it with suspicion. Another factor is that the LPA came as a power-sharing arrangement. It focused on establishing a unified government based on individuals -rather than on vision and policy- a process doomed naturally to fail. Once some elements realized they might lose power, they quickly turned against the GNA, as in the case of the HoR. The agreement overlooked and failed to address the root 


\section{Failure to deal with all the elements of fragility that affect the stability of the Libyan state will undermine any project for political stability}

causes of the issues facing the country. The LPA lacked a comprehensive plan that would respond to Libyans' collective grievances and establish a unified government and army.

In addition to their failure to uphold the principles of the LPA, the emerging institutions paved the way for foreign interventions to exacerbate the crisis. Both the UN recognized GNA and the challenging HoR formed alliances with regional powers, which came at the expense of Libya's sovereignty. The country quickly turned into a battleground between two rival camps: Turkey (allied with the GNA) versus Egypt, the UAE, France, and Russia (allied with the HoR). Not only did this hinder stabilization efforts, but it also shook any local trust in future democratization in Libya.

\section{The Fragility of the Libyan State}

The Libyan political climate is so chaotic that some scholars call it a de facto failed state with an internationally recognized national government."' According to the indicators of the Fragile States Index (FSI), "the fragility of the state, or the failure of the state can be defined as the inability of the ruling structure or the ruling institutions to perform their basic duties towards their citizens

Graph 1: Fragile States Index Overall Trend: Libya (2006-2020)

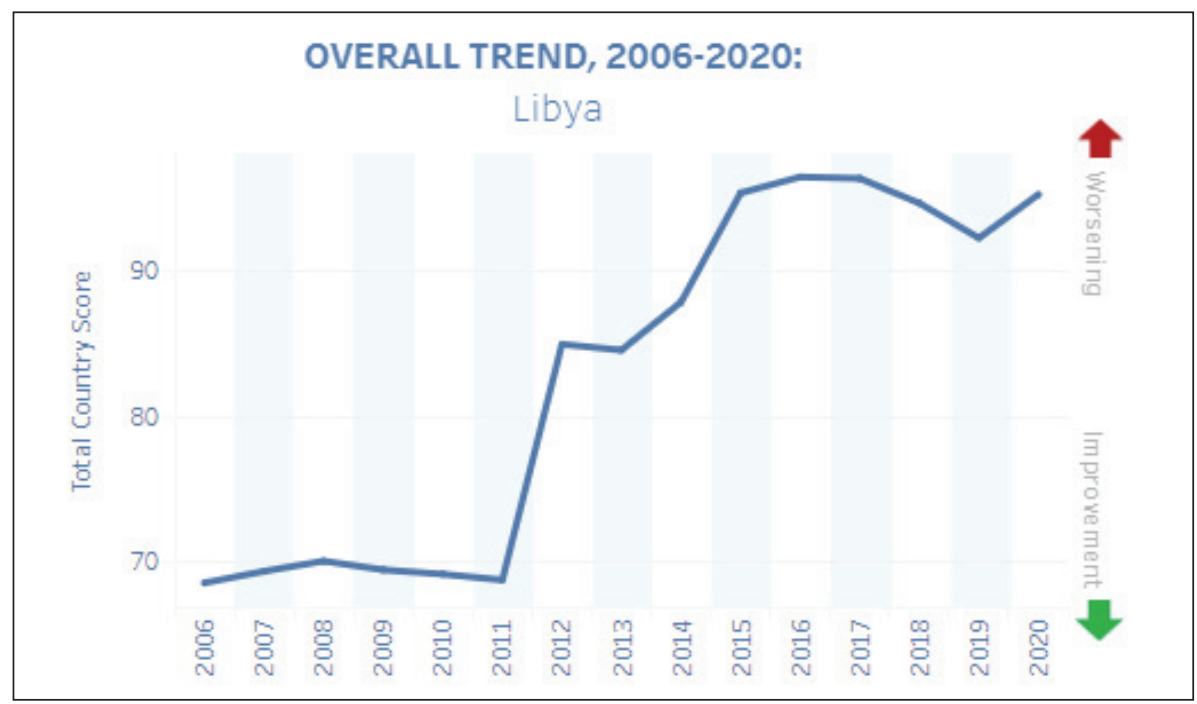

Source: The Fund for Peace 
and provide security, safety, basic services and guarantee the rights of the people, which leads to the partial or complete collapse of the state." ${ }^{8}$ The FSI is an analytical tool categorized in four segments -cohesion, economic, political, and social indicators- and twelve risk indicators. These include the security apparatus of a state, its factional elites and group grievances; its economic decline, inequality in economic development, human rights and brain drain; its state legitimacy, public service and its human rights and rule of law; its demographic pressures, refugees and internally displaced persons, and any ex- ternal intervention. ${ }^{9}$ Applying these indicators to Libya, the results are extremely worrisome. In 2019, Libya was on the verge of becoming an officially failed state with an FSI total score of $92.2 / 120$ placing Libya $28^{\text {th }}$ out of 178 countries. The situation was aggravated even further in 2020 , placing Libya in the $20^{\text {th }}$ rank with an FSI score of 95.2. (See graph 1).

When analyzed closely, these risk indicators should alarm the international community to take different positions and cultivate efforts to save Libya from indeed becoming a de facto failed state. What perpetuates

Graph 2: Fragile States Index Risk Indicators: Libya (2006-2020)

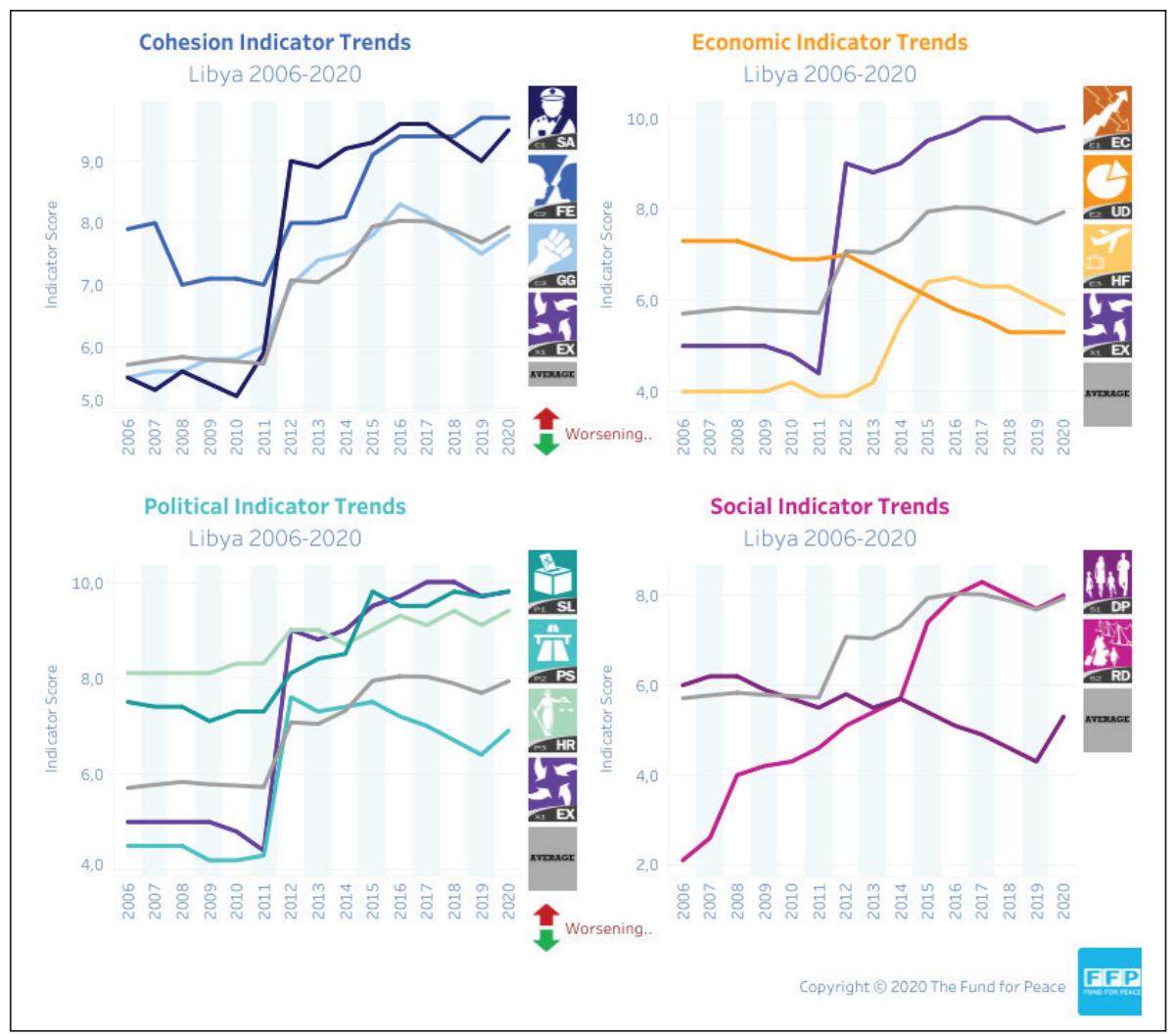

Source: The Fund for Peace 
Libya's political instability further pertains to its security apparatus (increased from $9 / 10$ in 2019 to $9.5 / 10$ in 2020), factionalized elites (with a stable score of $9.7 / 10$ both years), a deteriorated situation of human rights and rule of law (9.1 in 2019 to 9.4 in 2020), and finally in terms of external intervention (9.7 score in 2019 to 9.8 in 2020). ${ }^{10}$

Failure to deal with all the elements of fragility that affect the stability of the Libyan state will undermine any project for political stability.

\section{Prerequisites for Stability}

In order for political reform to be effective, local, regional, and super powers must not repeat their previous efforts expecting a different outcome. That includes not resorting to superficial solutions that recycle corruption and incompetence through political deals based solely on power sharing. It also includes foreign powers quitting their realpolitik zero-sum games of militarization and containment strategies, as they will not create sustainable political reform. Instead, such approaches aggravate the conflict and further increase Libya's political power vacuum and fragmentation. Sustainable political reform requires a comprehensive strategic plan coupled with a roadmap and a framework for implementation.

Before delving into this paper's recommendations, it is imperative to emphasize order as a pre-condition to any stabilization process. No polit- ical reform can take place without the establishment of order.

In societies that experience changes in political systems and institutions, Samuel Huntington argues in his book, 'Political Order in Changing Societies' that order and stability are crucial conditions for a successful transition. In fact, he concedes that security comes before democracy as societies' political systems transition. And while his contentions regarding such changes in the developing world are orientalist in nature, the argument that political decay or political development requires political order first, still stands. In opposition to his claims, however, economic and social development can contribute to the existence of political order if other conditions are satisfied. This article borrows Huntington's arguments, not to advance his orientalist rhetoric, but rather to highlight the importance of political order.

In the case of Libya, political, economic, and social disorder currently prevails. However, assuming that disorder alone will automatically hinder the development of political reform and stability is a logical fallacy. Instead, the derailed development experienced in Libya is caused by many issues including but not limited to a youth bulge, rentier economy, lack of effective institutions and distorting foreign interventions. First, Libya has a large young population which provides tremendous potential for progress; however, due to the high unemployment rate, young people are incentivized to join armed groups 
who provide financial support and political power. Second, the economic system in Libya has been rentier in nature. Rentier states or rentier economies derive national revenues from the rents collected from natural resources (oil). In this case, Libya collects rents derived from oil in exchange for services and the relief from tax imposition. This rentier process robs the public of their right to a democratic bargain of development plans. Third, what sets Libya apart from Egypt and Tunisia, for example, is the lack of political institutions as a necessary foundation for an effective, stable and sustainable democratization.

\section{A Proposal for Political Reform}

The proposed policy that we advocate is based on four main principles. First, the ending of hostilities and conflicts between Libyans, including militarized foreign interventions. This demand is extremely vital as it establishes order as a precondition for the later stages. Second, the adoption of a constitution as a necessary condition to resolve disputes over political legitimacy. Third, shaping the structure of democratic institutions through holding free and fair executive and legislative elections. Finally, the emphasis on transitional justice and sustainability as a basis for national reconciliation.

We support the Civic Forces Movement's national project for compatibility and stability. The project consists of four consecutive phases:

\section{The national assembly is} responsible for deciding on the necessary state-building measures Libya needs to adopt. It consequently sets the necessary and sufficient conditions for a successful transition to the executional phase

foundational, building, executional, and stability. Each stage includes strategic objectives that ensure the success and smooth transition to the next stage. Although the stages are arguably linear, each phase comprises various tracks that work simultaneously together to achieve the strategic objectives.

The foundational phase represents the current state in Libya. We refrain from calling it a transitional or an interim stage because Libya has already had five transitional stages and this has done nothing but hinder the country's political progress. The main strategic objectives of this stage include ending all hostilities, building trust and uniting political factions. The mechanism to accomplish these goals involves the cultivation and mobilization of the efforts of political rivals and the international community together around a unified plan for a Libyan political solution. Given the alarmingly low rates of public trust in state institutions, we advo- 


\section{We strongly urge local political rivals and regional powers along with the international community to consider this proposal as a comprehensive plan to achieve political settlement and reform in Libya}

cate for governmental reform to rebuild trust in the state by improving services. This stage, therefore, establishes order.

In the second stage, which is foundational in nature, we call for a plan for building the foundation of a civic Libyan state. The strategic objectives in this phase therefore include a referendum on the constitution, transitional justice, consensus on measures for building the Libyan state and finally participation in Mashrou' al-Engath (The National Project for Salvation). The importance of this stage is that it takes into consideration collective and group grievances (which have an FSI score of 7.8 in 2020) as central to the proposed solution. The mechanism for implementing this stage involves the creation of a Libyan national assembly composed of constitutional, legislative and executive tracks. The national assembly is responsible for deciding on the necessary state-building measures Libya needs to adopt. It consequently sets the necessary and sufficient conditions for a successful transition to the executional phase.
In the executional phase, the actual building of the constitutional institutions takes place. The strategic objectives include free and fair presidential and parliamentary elections, the formation of different authorities and the execution of the previously agreedupon measures for state building. Unlike other proposals that advocate for holding elections first, we argue that while elections are necessary for the democratization process, they are not sufficient. Furthermore, elections under the current situation will produce ineffective outcomes because the political infrastructure remains weak. The most important outcome of this stage is the adoption of the constitution, and while most other proposals demand this step first, we do not believe that institutions can miraculously solve political unrest. Empirical evidence confirms that institutions shape behavior, but that is not the case when sociopolitical and socioeconomic order is absent.

The final stage of the project is the stability phase. By this stage, elected bodies assume power with constitutional legitimacy. If we were to successfully reach this stage, the future of democratization in Libya will become a lot more foreseeable.

We strongly urge local political rivals and regional powers along with the international community to consider this proposal as a comprehensive plan to achieve political settlement and reform in Libya. This comprehensive project, therefore, sets precedence for a completely transformed and transitioned Libya. 


\section{Endnotes}

1. "Libyan Political Agreement," United Nations Mission for Support in Libya, (December 17, 2015), retrieved from https://unsmil.unmissions.org/ sites/default/files/Libyan\%20Political\%20Agreement\%20-\%20ENG\%20.pdf, p. 2.

2. Ahmed Elumami, "Suicide Attackers Storm HQ of Libya's Election Commission, 12 Dead," Reuters, (May 2, 2018), retrieved September 24, 2020, from https://www.reuters.com/article/us-libya-security/suicide-attackers-storm-hq-of-libyas-election-commission-12-dead-idUSKBN1I3131.

3. Abdulkader Assad, "Gunmen Loyal to Haftar Attack Traghan Polling Station, Hinder Elections," The Libya Observer, (August 25, 2020), retrieved September 24, 2020, from https://www.libyaobserver.ly/news/gunmen-loyal-haftar-attack-traghan-polling-station-hinder-elections.

4. Patrick Wintour, "Libya May Not Be Ready for Democracy, Says Military Strongman," The Guardian, (January 10, 2018), retrieved September 25, 2020, from https://www.theguardian.com/ world/2018/jan/10/libya-may-not-be-ready-fordemocracy-says-military-strongman.
5. Sami Zabtia, "Following Serraj's Call For March Eections: HNEC Says It Is Not Ready For Elections Due to Insufficient Funds," Libya Herald, (September 5, 2020), retrieved from https://www.libyaherald.com/2020/09/05/following-serrajs-callfor-march-elections-hnec-says-it-is-not-readyfor-elections-due-to-insufficient-funds/.

6. "Arab Barometer V: Libya Country Report," Arab Barometer, (2019), retrieved from https://www. arabbarometer.org/wp-content/uploads/ABV_ Libya_Report_Public-Opinion_Arab-Barometer_2019-1.pdf, p. 2.

7. Tim Milosch, "A Region Reborn? Political Change in the Post-Uprisings Maghreb" in Sallama Shaker and Steven Childs (eds), The Middle East in the Global Era, (San Diego: Cognella Academic Publishing, 2020) pp. 283-319.

8. "Libya Country Profile, Fragile States Index," The Fund for Peace, retrieved September 25, 2020 from https://fragilestatesindex.org/country-data/.

9. "Libya Country Profile, Fragile States Index."

10. Fragile States Index, Libya Country Dashboard, The Fund for Peace, retrieved from https:// fragilestatesindex.org/country-data/. 


\section{SETA}

\section{Turkey and Russia in Syria | Testing the extremes}

October 2020 | Hasan Yükselen

This book will answer the key research question of which characteristics (changing or enduring) of the Syrian War caused Turkey and Russia to oscillate between the extremes of war and alliance.

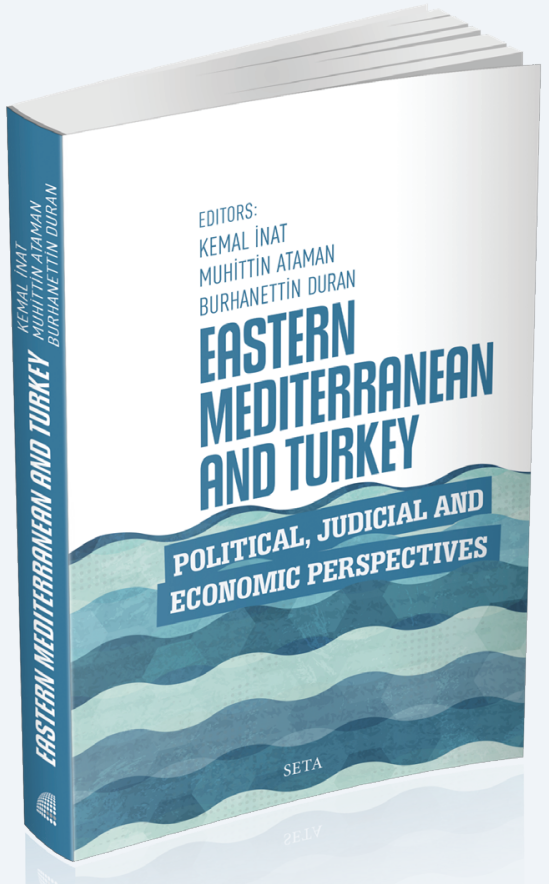

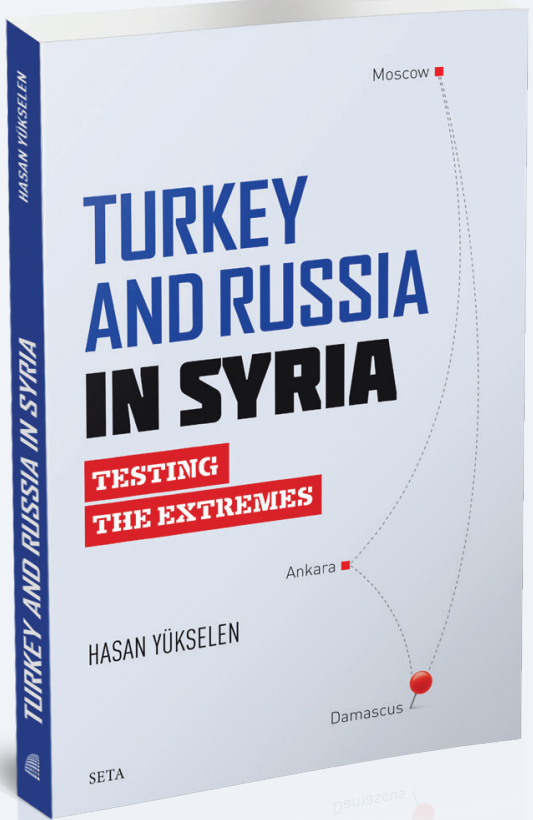

\section{Eastern Mediterranean and Turkey}

July 2020 | Kemal İnat, Muhittin Ataman, Burhanettin Duran

This book examines the political, legal, and economic dimensions of the Eastern Mediterranean, and brings new insights into the recent developments and Turkey's policy in the region. 